\title{
PENJAJAKAN PELUANG INDUSTRY MIKRO OLAHRAGA PADA PROGRAM STUDI PENDIDIKAN JASMANI KESEHATAN DAN REKREASI UKAW KUPANG
}

\author{
Program Studi Pendidikan Kesehatan dan Rekreasi \\ Universitas Kristen Artha Wacana Kupang 1,2,3,4 \\ sinlaeloe.andry@yahoo.co.id
}

Andry Sinlaeloe ${ }^{1,}$ Agustinus J. Nafie ${ }^{2}$, Fredik Nope ${ }^{3}$, Melvianus Selan $^{4}$

\begin{abstract}
ABSTRAK
Dunia Sport industry menjadi salah satu peluang yang sangat berperan penting dalam kemajuan dunia olahraga. Industri Olahraga adalah kegiatan bisnis dibidang olahraga dalam bentuk produk barang dan/atau jasa. Setiap pelaksanaan industri olahraga yang dilakukan oleh Pemerintah, pemerintah daerah, dan/atau masyarakat wajib memperhatikan tujuan keolahragaan nasional serta prinsip penyelenggaraan kegiatan olahraga. olahraga telah menjadi industri unggulan sebagai pemasok devisa negara. Hal ini seharusnya telah menyadarkan kita untuk menjadikan olahraga sebagai penggerak laju pertumbuhan ekonomi yang membuka kesempatan kerja, membuka peluang usaha dan ikut mensejahterakan masyrakat. Metode penelitian ini adalah metode kualitatif. Teknik pengumpulan data mengunakan observasi, wawancara mendalam, dan dokumentasi. Subjek penelitian sebanyak 16 orang. Teknik analisis data mengunakan triangulasi data. Hasil analisa data menunjukan bahwa industry mikro olahraga memiliki peluang dari sekmen Sport performance / penampilan olahraga, Sport Production /produksi olahraga, dan Sport Promotion / Promosi Olahraga. Dapat disimpulkan progdi Pendidikan Jasmani Kesehatan dan Rekresi Universitas Kristen Artha Wacana Kupang memiliki peluang dalam mengembangkan industry mikro olahraga.
\end{abstract}

Kata kunci: penjajakan, peluang, industry, mikro, dan olahraga

\begin{abstract}
The sports industry of the world is one of the most important opportunities in the advancement of sports in the world. The sports industry is a business activity in the field of sports in form of products and/or services. Every performance of the sports industry done by governments, local governments, and/or societies is required to consider the national sports objectives and the principles governing sports activities. Sports have become a leading industry as state foreign exchange suppliers. It should wake us up to make sports as a booster of economic growth that opens up job opportunities, opens up business opportunities, and contributes to community welfare. This research method is qualitative. Data collection techniques include observation, indepth interviews, and documentation. Research subjects as much as 16 people. Data analysis technique using data triangulation. The results of the data analysis show that the micro-sports industry has the opportunity of the sports performance sector, sports production, and sports industry. It could be concluded that the Physical Education, Health and The reconstruction study program of the Artha Wacana Christian University Kupang has the opportunity of developing the micro-sports industry.
\end{abstract}

Keywords: bookmaking, opportunity, industry, micro, and sports

Dipublikasikan Oleh :

UPT Publikasi dan Pengelolaan Jurnal

Universitas Islam Kalimantan Muhammad Arsyad Al-Banjari Banjarmasin 


\section{PENDAHULUAN}

Industri olahraga merupakan salah satu aspek yang sangat penting dalam perkembangan ekonomi suatau negara. Di berbagai negara industri maju dan modern seperti di Amerika, Inggris, Jerman, Prancis, Italia, Korea dan China, olahraga telah menjadi industri unggulan sebagai pemasok devisa negara. Selain itu olahraga juga dirancang sebagai industri moderen berskala global. Di Indonesia perkembangan industri olahraga masih memerlukan peran serta dari pemerintah dalam mensosialisasikan besarnya peluang wirausaha dalam bidang olahraga. Indonesia sudah harus melakukan industrialisasi olahraga sebagai salah satu daya Tarik bagi negaranegara barat dan Amerika Serikat untuk berinvestasi dalam bidang olahraga merupakan moment tepat untuk mengembangkan industrialisasi olahraga (Ibnu, 2011: 1).

Perkembangan dunia olahraga saat ini telah memasuki ranah dunia industri. Hal ini dapat dilihat dengan semakin bertambah banyaknya produk barang olahraga seperti sepatu, baju olahraga, peralatan fitness atau berupa bentuk jasa-jasa dibidang olahraga. Berkembangnya dunia bisnis olahraga seperti ini menjadi keuntungan tersendiri bagi masyrakat dalam memenuhi kebutuhan-kebutuhan olahraga. Bukan hanya sebagai konsumen, peluang menjadi bagian dan turut serta dalam perkembangan bisnis olahraga terbuka begitu lebar. Jadi secara singkat kita dapat simpulkan bahwa dunia olahraga bukan hanya sebatas dalam peranannya sebagai alat untuk perkembangan fisik mental, dalam menyehatkan tubuh, sarana rekreasi, atau sebatas kompetisi. Tetapi olahraga juga bisa sebagai sumber penghasilan ekonomi masyarakat, juga bisa menjadi sarana untuk mengangkat harkat dan derajat Negara

Industri Olahraga dalam Undang-undang Sistem Keolahragaan Nasional diatur dalam Bab XVI. Pengertian dan batasan Industri Olahraga adalah kegiatan bisnis bidang olahraga dalam bentuk produk barang dan/atau jasa. Setiap pelaksanaan industri olahraga yang dilakukan oleh Pemerintah, pemerintah daerah, dan/atau masyarakat wajib memperhatikan tujuan keolahragaan nasional serta prinsip penyelenggaraan kegiatan olah- raga (pasal 78). Industri olahraga dapat berbentuk prasarana dan sarana yang diproduksi, diperjualbelikan, dan/atau disewakan untuk masyarakat (pasal 79 ayat 1).

Industri olahraga dapat berbentuk jasa penjualan kegiatan cabang olahraga sebagai produk utama yang dikemas secara profesional yang meliputi: Masyarakat yang melakukan usaha industri olahraga sebagaimana dimaksud pada ayat (1) dan ayat (2) dapat bermitra de- ngan Pemerintah, pemerintah daerah, organi- sasi olahraga dan/atau organisasi lain, baik dalam negeri maupun luar negeri (pasal 79 ayat (3). Dalam melaksanakan kemitraan sebagai- mana dimaksud dalam ayat (3) masyarakat membentuk badan usaha sesuai dengan peraturan perundang-undangan.

Merujuk pada Tema besar peringatan Hari Olahraga Nasional (haornas) Tahun 2020" sport science, sport tourism, sport industry untuk bangkit dan bergerak" hal ini menegaskan kebijakan pemerintah yang berperspektif multidimensional dalam menunjang keberhasilan arah pembagaunan olahraga secara nasional. Oleh karena itu selaku institusi pendidikan yang memiliki program studi pendidikan olahraga kesehatan dan rekreasi suda seharusnya turut mendukung kebijakan tersebut dalam mengembangkan industry olahraga di lingkungan universitas serta masyarakat.

\section{Industri Olahraga}

Menurut Pitts; Fielding, and Miller (1994) industri olahraga adalah "setiap produk, barang, servis, tempat, orang-orang dengan pemikiran yang ditawarkan pada publik berkaitan dengan olahraga. Dikutip dari pernyataan Nuryadi (2010: 10); Sport Industry adalah sebuah industri yang menciptakan nilai tambah dengan memproduksi dan menyediakan olahraga yang berkaitan dengan peralatan dan layanan. Sport marketing adalah penerapan spesifik prinsip dan proses pemasaran kepada produk olahraga dan untuk memasarkan produk nirlaba olahraga melalui asosiasi dengan olahraga.

industri adalah sekelompok perusahaan yang bisa menghasil- kan sebuah produk yang dapat saling menggantikan antara yang satu dengan yang lainnya. Menurut Sahaan, industri adalah bagian dari sebuah proses yang mengolah barang mentah menjadi barang jadi sehingga menjadi sebuah barang baru yang memiliki nilai lebih bagi kebutuhan masyarakat. Sedangkan menurut Wirasti dan Natalia, industri diartikan sebagai pengolahan barang setengah jadi menjadi barang yang telah jadi sehingga dapat mendatang- kan sebuah keuntungan bagi pelaksanaannya (Hadiwinata, 2002). Dengan demikian, dapat disimpulkan bahwa pengertian industri ialah seluruh bentuk dari kegiatan ekonomi yang mengolah bahan 
baku dan atau memanfaatkan sumber daya industri, sehingga dapat menghasilkan barang yang memiliki nilai tambah atau manfaat yang lebih tinggi, termasuk juga jasa industri.

Industri Olahraga merupakan proses mengolah barang dan jasa menjadi barang jadi ataupun setengah jadi dalam bidang olah raga dengan tujuan untuk mendapatkan keuntungan sehingga dapat memenuhi kebutuhan. Berdasarkan penjelasan di atas, bahwa bidang industri terbagi menjadi dua yaitu industri barang dan industri jasa. Begitupun dengan industri olahraga, diamana hasil akhir atau produk yang dihasilkan bisa berupa barang maupun jasa. Industri barang dalam cakupan bidang olahraga diantaranya adalah pembuatan alat-alat olahraga, penjualan perlengkapan olahraga seperti sepatu, baju, aksesories dan sebagainya. Sedangkan industri jasa dalam bidang olahraga seperti pembuatan sekolah olahraga seperti akademi futsal, bola basket dan sebagainya, pengadaan event olahraga, penyewaan sarana olahraga dan sebagainya.

Menurut Pitts; Fielding, and Miller (1994) industri olahraga adalah "setiap produk, barang, servis, tempat, orang-orang dengan pemikiran yang ditawarkan pada publik berkaitan dengan olahraga. Dikutip dari pernyataan Nuryadi (2010: 10); Sport Industry adalah sebuah industri yang menciptakan nilai tambah dengan memproduksi dan menyediakan olahraga yang berkaitan dengan peralatan dan layanan. Sport marketing adalah penerapan spesifik prinsip dan proses pemasaran kepada produk olahraga dan untuk memasarkan produk nirlaba olahraga melalui asosiasi dengan olahraga.

\section{Peluang industry olahraga}

Produk dari sebuah industri olahraga akan memiliki peluang yang baik apabila mampu bersaing dengan produk yang dihasilkan oleh berbagai negara dengan berbagai keunggulannya. Produk yang tidak memiliki keunggulan bersaing atau meniru produk lain akan tergusur dan terpuruk. Agar produk industri olahraga mampu bersaing dengan produk dari berbagai negara maka dilakukan proses pengembangan industri olahraga. Pengembangan industri olahraga dapat mengerti dan memahami konsep dari kondisi pasar pada saat sekarang. Tanpa hal itu industri olahraga mampu untuk melakukan analisis dan mengambil suatu keputusan dalam menentukan tindakan yang paling baik dan tepat bagi pengembangan usaha dirinya sendiri. Pengembangan Industri olahraga dapat diaplikasikan dalam kehidupan ini melalui kajian produk hasil industri olahraga. Industri olahraga sesuai dengan tipe produknya menurut Parks, Zanger and Ouarterman (1998) dalam Priyono Bambang (2012) terdapat tiga segmen yaitu:

1. Sport performance / penampilan olahraga

2. Sport Production / produksi olahraga,

3. Sport Promotion / Promosi Olahraga.

Melihat tipe produk di atas dapat dijadikan rekomendasi untuk menghasilkan industri olahraga. Pada sport performance, yakni sebuah barang atau jasa yang nantinya dapat mendukung performance atau penampilan pada sebuah kelompok olahraga. Industri yang akan memenuhi kebutuhan olahraga sekolah dalam mendukung kegiatan olahraga seperti pemenuhan sarana-prasarana, Baju, sepatu khusus olahraga. Sport Production pada tipe ini industri olahraga dapat bergerak dalam pemasaran fasilitas tambahan dalam olahraga misalnya adalah pemenuhan bola dan peralatan pada semua cabang olahraga. Sport Promotion tipe ini industri dapat bergerak dalam pemenuhan kegiatan olahraga atau acara-acara yang bertemakan olahraga. Selain itu bentuk industri ini juga bergerak dalam hal pemasaran dan alat bidang keolahragaan.

Pengembangan Industri olahraga dalam referensi lain juga dapat memperhatikan tipe industri olahraga dapat diaplikasikan dalam kehidupan ini melalui kajian produk hasil industri olahraga menurut Yang Yue (2006) mengatakan bahwa "industri olahraga di China dimulai sejak reformasi dan membuka pintu dunia pada tahun 1978, yang lebih khusus lagi setelah calon atau kandidat olimpiade tahun 2002." Selanjutnya, Yang Yue (2006) menambahkan bahwa di negara China industri olahraga dibagi menjadi 2, antara lain:

1. Sport Service Industry (Layanan Industri Olahraga).

2. Sport Good Industry (Peralatan Industri Olahraga)

Membangun Industri olahraga perlu kiranya mempersiapkan iklim usaha industri olahraga. Bambang Priyono (2012: 116) terkait re-orientasi program dalam pengembangan industri keolahragaan, mengatakan bahwa beberapa hal tersebut sebagai berikut:

1. Pengembangan budaya olahraga Budaya olahraga merupakan landasan utama dalam pembangunan olahraga nasional. Budaya olahraga merupakan sikap dan kebiasaan masyarakat untuk senang 
berolahraga dan menjadikan olahraga sebagai gaya hidup sehat. Pengembangan budaya olahraga ini dapat dimulai dari lingkup individu dan keluarga dengan cara memberikan apresiasi terhadap makna dan manfaat olahraga bagi peningkatan kesehatan dan kualitas hidup.

2. Persaingan olahraga regional dan internasional Prestasi olahraga nasional terus merosot di tingkat regional dan internasional. Kondisi ini disebabkan lemahnya daya saing olahraga nasional dibandingkan dengan negara-negara lain. Kebangkitan kekuatan baru dalam olahraga, baik di tingkat ASEAN, Asia, maupun dunia sangat berpengaruh terhadap posisi kekuatan olahraga Indonesia. Perkembangan olahraga di Thailand, Malaysia, China, dan beberapa negara pecahan Uni Soviet merupakan kekuatan-kekuatan yang mempengaruhi keputusan pembinaan olahraga pada umumnya di Indonesia.

3. Manajemen olahraga nasional Pendekatan integratif dalam penetapan kebijakan yang memungkinkan pembinaan dan pengembangan olahraga nasional secara harmonis, terpadu dan jangka panjang yang didukung dengan sistem pendanaan dengan prinsip kecukupan dan keberkelanjutan merupakan hal yang sangat penting dalam mendukung keberhasilan pembangunan olahraga.

4. Sarana prasarana olahraga serta penerapan riset dan Iptek Penerapan Iptek dalam pembinaan olahraga baik untuk meningkatan mutu proses belajarmengajar maupun pelatihan merupakan sebuah keniscayaan. Mutu proses menjamin tercapainya hasil belajar dan prestasi olahraga yang ditargetkan. Sulit dibayangkan pencapaian hasil belajar atau prestasi tinggi tanpa pemanfaatan Iptek. Tersedianya dukungan Iptek termasuk sarana laboratorium pengajaran dan pelatihan olahraga sangat diperlukan dalam upaya peningkatan prestasi. Sebagai contoh, keberhasilan prestasi olahraga negara lain seperti Australia dan China diantaranya karena persoalan ini.

5. Sinkronisasi program antara; pemerintah, masyarakat, dan swasta Kebijakan-kebijakan olahraga yang diambil oleh Pemerintah sangat diperlukan dan masih dominan untuk kelancaran proses di lapangan, seperti subsidi pembiayaan olahraga. Pihak masyarakat dan swasta sebagai pelaksana di lapangan, akan berlindung di balik kebijakan yang diputuskan pemerintah, sehingga dalam pelaksanaannya, pihak masyarakat atau swasta dapat berkerja tenang dan aman. Pihak ketiga pasar atau market, berkewajiban untuk memasyarakatkan atau mempopulerkan olahraga di masyarakat, agar sektor olahraga tidak hanya sebagai sektor nonprofit tetapi juga profit dan dapat dijual ke masyarakat.

\section{METODE}

Rancangan penelitian ini adalah menggunakan pendekatan deskriptif Kualitatif tentang penjajakan peluang industry mikro olahraga pada Program Studi Pendidikan Jasmani Kesehatan dan Rekreasi UKAW. metode penelitian yang digunakan dalam penelitian ini adalah metode penelitian kualitatif yang merupakan sebuah prosedur penelitian yang menghasilkan data deskriptif berupa kata-kata tertulis atau lisan dari orangorang dan perilaku yang dapat diamati (Moleong, 2007). Penelitian ini bertujan untuk mendapatkan informasi dan data-data mengenai peluang industry mikro olahraga pada progdi PJKR UKAW

\section{Subjek Penelitian}

Sampel dalam penelitian ini menggunakan teknik total sampling yang artinya keseluruhan populasi dijadikan sampel. Subjek dalam penelitian ini melibatkan 16 dosen di lingkungan Progdi PJKR UKAW Kupang

\section{Teknik Pengumpulan Data}

Dalam penelitian ini teknik pengumpulan data yang digunakan dilakukan dengan observasi (pengamatan), interview (wawancara), kuesioner (angket), dokumentasi dan gabungan keempatnya (triangulasi). Sugoiyono (2014) menyatakan bahwa dalam penelitian kualitatif, pengumpulan data dilakukan pada natural setting (kondisi yang alamiah), sumber data primer, dan teknik pengumpulan data lebih banyak pada observasi berperan serta (participant observation), wawancara mendalam (in depth interview) dan dokumentasi.

\section{Teknik Analisa Data}

Teknik analisa data dalam penelitian ini menggunakan model Miles dan Huberman dalam Sugiyono (2014: 246-253) mengemukakan bahwa aktivitas dalam analisis data kualitatif dilakukan secara interaktif dan berlangsung secara terus menerus sampai tuntas, sehingga datanya sudah jenuh. Aktivitas dalam analisis data, yaitu : 
1. Data Reduction (Reduksi Data) Data yang diperoleh dari lapangan jumlahnya cukup banyak, untuk itu maka perlu dicatat secara teliti dan rinci. Semakin lama peneliti ke lapangan, maka jumlah data akan semakin banyak, kompleks dan rumit.untuk itu perlu segera dilakukan analisis data melalui reduksi data. Mereduksi data berarti merangkum, meneliti hal-hal yang pokok, memfokuskan pada hal-hal yang penting , dicari tema dan polanya.

2. Data Display Dalam penelitian kualitatif, penyajian data bisa dilakukan dalam bentuk uraian singkat, bagan, hubungan antar kategori, flowchart, dan sejenisnya. Yang paling sering digunakan untuk menyajikan data dalam penelitian kualitatif adalah dengan teks yang bersifat naratif. Dalam hal ini peneliti akan menyajikan data dalam bentuk teks, untuk memperjelas hasil penelitian maka dapat dibantu dengan mencantumkan table atau gambar.

3. Conclusion Drawing/Verification Kesimpulan dalam penelitian kualitatif mungkin dapat menjawab rumusan masalah yang dirumuskan sejak awal, tetapi mungkin juga tidak, karena sepeerti telah dikemukakan bahwa masalah dan rumusan masalah dalam penelitian kualitatifmasi bersifat sementara dan akan berkembang setelah penelitian berada di lapangan. Kesimpulan dalam penelitian kualitatifn adalah merupakan temuan baru yang sebelumnya belum pernah ada.temuan dapat berupa deskripsi atau gambaran suatu obyek yang sebelumnya masih remangremang atau gelap sehingga setelah diteliti menjadi jelas, dapat berupa hubungan kausal atau interaktif. Hipotesis atau teori.

\section{PEMBAHASAN}

Industry olahraga berkembang dengan pesat dalam perkembangannya tidak terlepas dari kebutuhan manusia untuk mendapatkan hidup sehat jasmani, bahkan industry olahraga bukan hanya menjawab kebutuhan untuk hidup sehat tetai juga sengat berperan penting dalam pertumbuhan ekonomi suatu Negara dan menjadi bagian dalam menyumbang devisa terbesar bagi suatu Negara. Dengan melihat perkembangan industry olahraga pada Negara-negara maju seperti Amerika, Inggris, Jerman, Perancis, Italia, Spanyol, Belanda, Jepang, Korea Selatan dan China, olahraga telah menjadi industri unggulan sebagai pemasok devisa negara. Hal ini seharusnya telah menyadarkan kita untuk menjadikan olahraga sebagai penggerak laju pertumbuhan ekonomi yang membuka kesempatan kerja, membuka peluang usaha dan ikut mensejahterakan masyrakat.

Peluang usaha dalam dunia olahraga bukan haya sebatas kalangan pembissnis atau pedagan perorangan tetapi perkrmbangan dunia industry olahraga sudah seharusnya menjadi perhatian dalam dunia akademisi. Lewat system manajemen yang baik maka industry olahraga dapat dikembangan lewat dunia akademisi dalam menunjang perkembangan lembaga akademisi maupun kesejahtraan masyarakat lewat terbukanya lapangan kerja, adnya fasilitas olahraga yang dapat dijangkau untuk kegiatan olahraga baik itu olahraga pendidikan, olahraga prestasi, dan olahraga rekreasi.

Program Studi Pendidikan Jasmani Kesehatan dan Rekreasi Universitas Kristen Artha Wacana memiki Potensi dalam mengembangkan sport industry dari tiga segment sprot industri yakni Sport performance / penampilan olahraga, Sport Production / produksi olahraga, dan Sport Promotion / Promosi Olahraga. Ketiga segmen ini potensinya ada pada Progdi PJKR.

potensi segi penampilan olagraga / sport performance Progdi PJKR punya SDM yang baik di berbagai bidang olahraga yang dapat menunjang pengembangan sport industry baik itu dari segipendidikan olahraga, event olahraga, konsultan olahraga, perwasitan, pelatih, instruktur kebugaran, sport message fasilitas olahraga dan club olahraga. Potensi sport performance ini bagian dari suatu peluang bisnis olahraga yang dapat dikembangkan dan dikelolah oleh lembaga UKAW lewat yunit bisnis dangan pemanfaatan Progdi PJKR sebagai pelaksana.

Potensi segi produksi olahraga / sport production PJKR UKAW punya fasilitas olahraga yang dapat disewakan dalam bentuk penyedia lapang olahraga contohnya penyewaan lapangan basket, lapangan futsal dan lapangan voli sehingga fasilitas ini tikhaya dipergunaka ketika jam pembelajaran tetapi vasilitas tersebuat dapat dimanfaatkan dalam bisnis olahraga sehingga dapat mendukung perkembangan lembaga dari segi ekonomi. Fasilitas kolam renang yang dibutuhkan dalam proses pembelajara selalu disewa dengan besaran anggaran pertahun mencapai 150 juta. Melihat dari besarnya angagaran yang dibutuhkan dalam penyewaan kolam renang senyogiannya dapat menyadarkan kita akan potensi bisnis yang sangat menjanjikan hal ini dapat kita melihat dari SDA yang UKAW miliki yakni sumber air yang melimpah dan dapat dimanfaatkan untuk kolam renang.

Dalam penyewaan dan produksi fasilitas olahraga berupa lapangan basket, lapangan futsal, lapangan foli dan mempu memproduksi satu kolam renang maka fasilitas ini dapat membantu dalam menunjang kemajuan program studi PJKR di segi pendidikan dan fasilitas inipun dapat dipekerjakan untuk memeliahara 
fasilitas tersebut bahkan dapat memproduksi berbagai fasilitas olahraga lain serta dapat menunjang UKAW dari segi ekonomi, promosi dan pengembagan UKAW ke .depan.

Potensi dari sekmen Promosi Olahraga / Sport Promotion, dalam dunia industry sport market suda sangat berpeluang dalam bisnis olahraga. Progdi PJKR UKAW memiliki peluang dalam membuka toko olahraga ini bagian dari peluang bisnis dibidang olahraga yang paling potensial kerena kebutuhan akan perlengkapan olahraga sangant dibutukan olah pencinta olahraga. Olahraga pendidikan, olahraga prestasi, dan olahraga rekreasi sangat memerlukan perlengkapan olahraga untuk mendukung aktifitas olahraga.

Progdi PJKR saat ini suda menjajaki kerjasama dengan berbagai pihak/ penyedia produk perlengkapan olahraga dan progdi PJKR juga dapat memberi logo BETA PJKR dan UKAW pada beberapa produk perlengkapan olahraga maka hal ini juga menjadi suatu promosi Universitas di dunia perlengkapan olahraga.

Dari segi pasar Progdi PJKR memiliki target pasar yang besar. Yang menjadi target pasar tentu mahasiswa PJKR UKAW serta dapat membangan kerja sama dengan progdi PJKR dari Universitas lain yang ada di wilayah NTT sebagai bagian dari target pasar serta semua pencita olahraga terutama masyarakat oesapa dan sekitarnya. Ini menjadi target market yang potensial karena sampai pada saat ini di Kota Kupang juga belum ada toko olahraga.

Dalam pelaksanaan sprot industry perlu manajemen yang baik sehingga semuanya dapat berjalan oleh karena itu lembaga pelu menyediakan suatu yunit kusus yang mengurus bisnis sehingga semua potensi bisnis dari berbagai progdi dapat dikelola melalui suatu yunit yang mana dalam pengelolaan mengikuti statuta lembaga agar semuanya dapat tertata pada porsi masing masing sehingga saling mendukung dan membangun tanpa mengganggu tugas dan tanggung jawab dalam dunia pendidikan.

\section{KESIMPULAN}

Peluang potensial dari segi Sport performance / penampilan olahraga, Progdi PJKR punya SDM yang baik di berbagai bidang olahraga yang dapat menunjang pengembangan sport industry baik itu dari segipendidikan olahraga, event olahraga, konsultan olahraga, perwasitan, pelatih, instruktur kebugaran, sport message fasilitas olahraga dan club olahraga. Sport Production / produksi olahraga, dari segi produksi punya potensi dalam memproduksi kolam renag dengan memiliki sumber daya alam yang dapat mendukung yakni air yang bayak dari mata air hitam dan dapat memberikan fasiliitas olahraga berupa lapangan basket, lapangan futsal, dan lapangan foli serta laboratorium olahraga bekerja keras agar dapat memelihara asset tersebut. Sport Promotion / Promosi Olahraga. Dari segi ini dapat menyediakan sport market untuk dapat menangkap target market melalui penyediaan perlengkapan olahraga dan mempromosikan universitas dan progdi PJKR lewat perlengkapan yang berlogo beta PJKR UKAW.

\section{REFERENSI}

Hadiwinata, Bob Sugeng. 2002. Politik Bisnis Internasional. Yogyakarta: Kanisus.

Ibnu. (2011). Visi, Misi, Sasaran dan Program Kadin Untuk Olahraga Nasional (online), (http://sport.ghiboo. com/visi-misi-sasaran-dan-programkadin-untuk-olahraga-nasional, diakses 25 Mei 2020).

Moleong, Lexy J. (2007) Metodologi Penelitian Kualitatif, Bandung: Penerbit PT Remaja Rosdakarya Offset,

Nuryadi. (2010). Industri Olahraga (Sport Industry). Online. http:// ebookbrowse.com. Diakses 13 juni 2020.

Pitts B.G, Fielding, L.W., and Miller (1994). Industry Segmentation Theory and Sport Industry. Developing a Spoort Industry Segmentation Model Sport Marketing Quarterly. 3. 1994. (Morgantown, WV: Titness Information Technologi, Inc).

Priyono. Bambang. 2012. Pengembangan Pembangunan Industri Keolahragaan Berdasarkan Pendekatan Pengaturan Manajemen Pengelolaan Kegiatan Olahraga. Jurnal Media Ilmu Keolahragaan Indonesia. 2 (2): 112-123.

Sugiyono. (2014). Metode Penelitian Pendidikan Pendekatan Kuantitatif, Kualitatif, dan R\&D. Bandung: Alfabeta

Undang- undang RI No 3 Tahun 2005 Tentang Sistem Keolahragaan Nasional. Kementrian.Negara Pemuda dan Olahraga Republik Indonesia

Dipublikasikan Oleh : 